\title{
Managing the Risk of Customer Integration
}

\author{
ELLEN ENKEL, University of St. Gallen \\ CHRISTOPH KAUSCH, University of St. Gallen \\ OLIVER GASSMANN, University of St. Gallen
}

\begin{abstract}
The necessity and the advantages of integrating customers into the innovation process are widely recognized. There are, however, inherent risks to customer integration that can be reduced by comprehensive risk management methods. Based on intensive desk research and in-depth workshops with nine companies, this article provides a detailed description of the various risks and offers advice on how to minimize them. Diverse risk management methods theoretical backgrounds are introduced, while examples from companies that have had vast experience with all aspects of customer integration illustrate their practical applicability.
\end{abstract}

(c) 2005 Elsevier Ltd. All rights reserved.

Keywords: Open innovation, Innovation process, Customer integration, Risk management

\section{Introduction}

Customer integration into the innovation process is about to become best practice. Empirical studies have established that customer integration increases a company's potential for innovation (Urban and von Hippel, 1988). Among its many advantages are: early customer integration leads to a stronger relationship with the partner, a better understanding of market needs, fewer errors in the early development process, and a better product quality. These advantages do not only apply to the innovation process's macrolevel but also to the microlevel. Customers can provide first-hand information regarding their needs, can help create innovative ideas for new products, and provide feedback regarding concepts and prototypes (Bruce and Biemans, 1995).

When customer integration is considered, one should remember that customers are not only end-consumers but can be found along the whole value chain.
The question of how to integrate customers has been widely discussed. Various concepts have been developed and are being tried out. Best known are von Hippel's lead user approach (von Hippel, 1986) according to which trendsetting customers are identified and integrated, the empathic design method (Leonard and Rayport, 1997) which examines customers' use of existing products and analyzes their behavior, and, most recently, the IT-based virtual customer integration (Dahan and Hauser, 2002) which makes use of customers' ideas with the aid of purpose-designed toolkits and online communities.

Whereas the positive aspects of customer integration and its implementation in the innovation process are a focus of scientific interest, the negative sides have so far met with little attention. However, the inherent risks should not be neglected: the company's loss of know-how to the customer, the company's dependence on customers, and the company being limited to only incremental innovations, are just a few of these risks. The consequences of these risks are, however, wide ranging: from financial disaster through investment in the wrong product, to supplying a competitor with know-how via a disloyal integrated customer.

The indisputable risks of customer integration have to be weighed carefully against its established advantages, but should not lead to abandoning the concept altogether. An intelligent risk management can minimize the dangers. This article will focus on this minimization.

\section{Minimizing the Risk of Customer Integration}

The primary risk, even before customer integration into the innovation process, is in respect of innovations themselves: many of them fail dismally. This is why, apart from the wish to increase their innovation potential, companies combined forces in order to 
better identify customers' wishes in the early 1990s (Miotti and Sachwald, 2003). At the same time, more and more companies wished to commercialize both their own ideas and external innovations and tried to deploy other companies' processes for their internal research activities. In 1995, the input of external knowledge in respect of innovative products amounted to 34-65\% (Conway, 1995). This required a considerable change in innovation policy: the hitherto solid boundaries between a company and the outside world had to be transformed into a semi-permeable membrane enabling at least a limited flow of information. This opening of the innovation process is called the "open innovation" paradigm (Chesbrough, 2003; Gassmann and Enkel, 2004). It comprises three archetypes of the open innovation process - the outside-in process (integrating external knowledge, customers and suppliers); the inside-out process (selling/licensing ideas outside the company); and the coupled process (a combination of both, mostly through cooperation with competitive or complementary companies) (Gassmann and En$\mathrm{kel}, 2004)$. Customer integration is a phenomenon of the first process type. The management of customer integration's inherent risks has been discussed by some authors (Becker and Peters, 1998; Gassmann and von Zedwitz, 1999), although not within the open innovation context.

Customer integration has gained importance within the open innovation model's reference frame, complementing, and sometimes even overtaking, the longer-standing cooperation with suppliers and scientific partners. For example, Zumtobel $A G$, a global market leader in electronic light technology, stresses the importance of open innovation with regard to customers, since it derives many innovative impulses from international light designers and architects. However, the history of customer integration has not always been one of unequivocal success. Rasselstein Hoesch, a producer of tinplate, toyed with a concept for cans that could be closed again after opening. A can-producing customer was integrated into the early phase of the innovation process, but because he would have needed new production units to manufacture those cans, Rasselstein Hoesch eventually discarded this idea. Another example of an unsuccessful integration is SIG allCap's (packing solutions) cooperation with a customer at an early stage of the innovation process. After jointly generating an idea for a new product and developing it further to a solid concept, the customer took this know-how to a competitor for the final product development.

\section{Research Methodology and Data Sample}

The results presented and analyzed below were gained from a research project that ran from October 2003 to November 2004 and concentrated on all as- pects of customer integration. In a first phase, a total of 141 companies were questioned on their experience with customer integration by means of a questionnaire. These companies were spread across different industries, as Figure 1 illustrates, and were of different sizes (19\% had under 1000 employees, $42 \% 1000-10,000$ employees and 39\% more than $10,000)$. The effort aimed to illustrate customer integration behavior across industries and company sizes to come up with more general than industryor size-specific results.

In a second phase, nine companies representing this sample were selected for in-depth case studies due to their experience with customer integration projects, but also due to their goal to develop a risk management system that would decrease the risks associated with customer integration projects that they had already experienced many times. These nine companies (BASF, EADS, Getzner Werkstoffe, Helbling Technik, Henkel, KABA, Merck, Schindler Elevators, and SIG allCap), each with a different technical background and products, were chosen to participate in a series of workshops focusing on this subject. Extensive data were collected from these companies, which formed the basis of the nine individual indepth case studies on their customer integration activities and the risks they face in the process. In order to discuss risk minimizing issues, the participating companies over a period of nine months met in seven workshops, organized and moderated by the authors of this article. Each workshop centered on one topic that had been previously identified as crucial for dealing with the risks of customer integration. From each company, two experts provided examples of their experience with the topic of the day; the subsequent discussion contributed to a better understanding of the problems and assisted in finding more general applicable results than company- or project-specific solutions. The deliberately limited number of the participants facilitated intensive discussions and an open exchange of best and

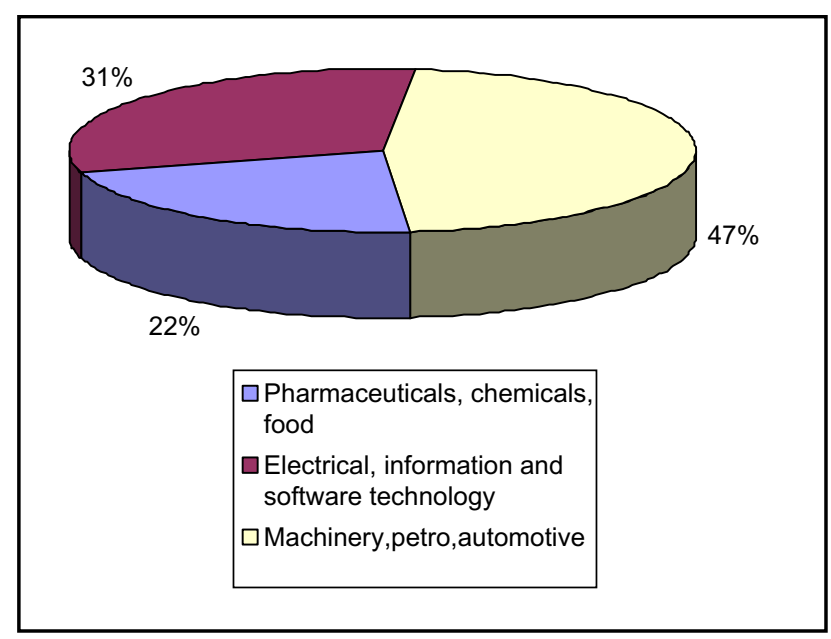

Figure 1 Industries of the Sample Companies 
bad practices within the companies. After each workshop, a list of general best practices and those to be avoided was drawn up. These results as well as the findings from the in-depth case studies and from the questionnaire at the start of the research project are presented in this article.

\section{Risk Management in Customer Integration}

With regard to minimizing risks, it is necessary to clarify first which risks are most important to the company, and therefore need substantial attention, and which are not important. Risks have a different significance for different companies, depending on their branch of industry and product. These risks are: loss of know-how through disloyal customers, dependence on customers' views, dependence on customers' demands or personality, limitation to mere incremental innovation, serving a niche market only and misunderstandings between customers and employees. The discussion of these risks forms the following section's structure.

The risks are not listed according to their frequency or general importance, but rather as they were prioritized by the majority of the workshop participants. Figure 2 shows when these risks occur in the collaboration process with the customer.

\section{Loss of Know-how}

The early innovation phase, especially the search field process, is inspired by - and in turn inspires the company's innovation strategy (Lichtenthaler, 2003). This strategy presupposes certain distinct skills and knowledge pertaining to the company's existing and future products. Its employees' implicit knowledge as well as the explicit knowledge from internal or external sources are fundamental to the innovation process (von Hippel, 1998). Whenever a customer is integrated into the company's search field or innovation process, he almost unavoidably acquires company know-how while contributing his own knowledge or ideas (Lukas and Ferrell, 2000). The obvious risk of integrating a customer is that he could use the company know-how for his own purposes - this risk may (but, again, may not) be negligible - or that he could trade it to a competitor, which is far more dangerous. The following illustrates this point graphically: a SIG allCap customer that was integrated into an innovation project, took the company's know-how and his own ideas to a competitor, thus not only depriving SIG allCap of the potential innovative product, but also increasing the competitor's innovative power to SIG allCap's detriment.

Another risk involving know-how is the possible conflict regarding the ownership of ideas which could arise in the course of the innovation process through the combination of company and customer knowhow (Hagedoorn, 2003). The company may feel that all the ideas generated during the innovation process are company property, but unless this was agreed upon beforehand, a customer may claim a joint, or even the full, ownership of the ideas. This problem is aggravated if the know-how that the customer supposedly contributed had already existed in the company (so-called contamination with customer's knowledge) - which happened at IBM and at KABA and led to a quarrel about intellectual property rights.

As far as know-how protection is concerned, an efficient risk management method can fall back on several measures which have proved to be successful in practice:

In keeping with the saying "make sure you know whom you are dealing with", the first step should

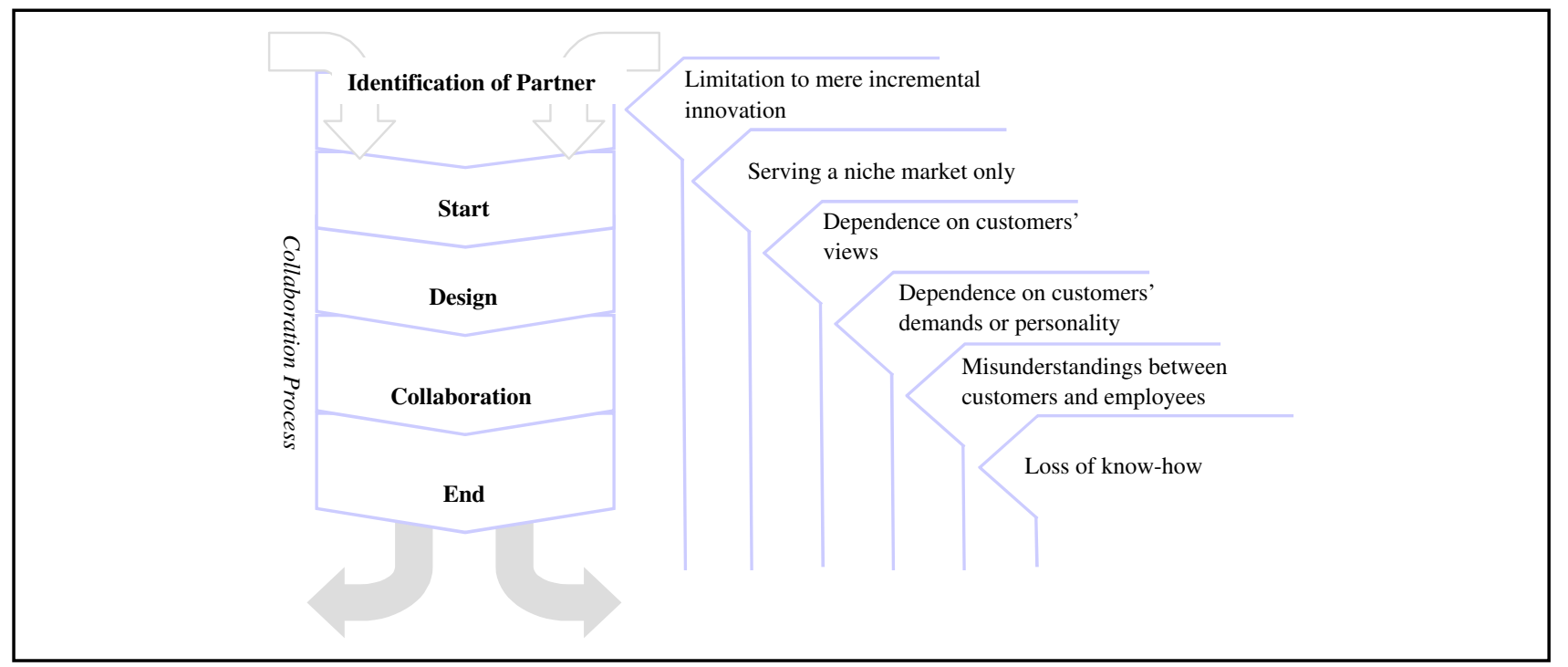

Figure 2 Risks According to the Stage of Customer Collaboration 
be to involve only trustworthy customers, preferably ones that have had long-standing contact and alliances with the company, or that had been "tested" before with minor projects. The second step should be the choice of the right moment for customer integration: as early as necessary, but as late as possible. This ensures that the customer learns as little about the company know-how as late as possible, but contributes his own ideas at a moment when they still have a decisive impact.

The most important risk management activity with regard to a loss of know-how is the provision of a variety of specific agreements concerning the intellectual property. These should comprise non-disclosure agreements, lists detailing who contributes which know-how to avoid contamination conflicts, and agreements on who is going to own the outcome of the innovation process. In all these agreements, the risk manager has to strike a delicate balance between the protection of company know-how on the one hand, and the necessary freedom to increase creativity and motivation on the other hand. This balance can best be achieved if the various agreements are set up according to the innovation process's different phases. It stands to reason, however, that non-disclosure agreements should always be signed before revealing company knowledge to a customer, no matter in which phase.

\section{Dependence on Customers' Views}

A customer who actively supports the early innovation process, consciously or subconsciously puts his stamp on the outcome. His point of view and his specific interests in a product influence the combined search for innovative ideas' direction (Wynstra and Pierick, 2000). This influence contains the inherent risk of customers agreeing to be integrated into the innovation process mainly because they expect a personal benefit, as illustrated by the Rasselstein Hoesch case (von Hippel, 1986). This mind-set often prevents innovative ideas from being realized because they could interfere with the customers' own line of production if they also happen to be producers. Even if they are end users, who do not aspire to any monetary profit from a possible innovative product, their interests seldom include developments that may arise from the process but which are of no immediate, or obvious use to them. When Sefar, market leader in filtration systems, presented their new radical idea of enzyme immobilization on fabrics for possible collaboration to the industry producing enzymes and instruments, the idea was said to be uninteresting. This was due to the fact that this industry had no desire to lose market share by helping develop a product which makes expensive instruments obsolete.

The main risk-reducing factor in this respect is the choice of the "right" customers - the key factor in customer integration. The classification of customers into "normal" customers and lead users (Herstatt and von Hippel, 1992) is a well-established concept by now. Normal customers can be integrated into the main domain of the innovative process, i.e. passively in conventional market research, or more actively as beta testers of products in a late phase of the innovation process. When they are integrated more actively, especially to discover their needs via toolkits, risk management consists of ensuring that their numbers are large enough to produce a representative outcome in order to even out possibly limited views.

Lead users are the preferred customers for integration into the early innovation process (Lilien et al., 2002). Empirical studies have revealed that there are lead users in several industries and that they are able to develop novel solutions for their needs (Herstatt and von Hippel, 1992). They perceive future trends earlier than others, and are able to provide research departments with this knowledge. But because lead users think differently from other customers, their involvement runs the great inherent risk that they do not follow the trends that the majority of customers do and which are needed for an economy of scale.

Zumtobel Staff, a leading company in the electronic light technology, integrates architects and light designers as lead users into their early innovation phases. But the innovative light solutions developed with renowned architects were scarcely suitable for the mass market. Zumtobel Staff was unable to sell these products to a broad range of customers because the trendsetting light designers and architects were thinking too differently from Zumtobel Staff's main customers' group. Büchi, a market leader in instruments for the vaporization of fluids produced for the chemical and pharmaceutical industry as well as for university labs and research centers, developed their blockbuster 10 years ago with one of their main customers. Because of the huge market success, they used the same collaboration methodology with one of their main customers in order to create another blockbuster two years later. The product that they subsequently launched was beyond all market success expectations.

Our data established a plethora of criteria for choosing the right lead customers. The most important criteria are that the customer needs to be either a trendsetter or market leader, according to the product the company wants to develop. The reputation of the customer also plays an important role as well as the PR potential that can be used to present the collaboration to the public. To minimize the market risk, the proposed integrated customer's sales potential is also important as well whether he is a branch representative or not. In order to facilitate cooperation, a former positive experience helps as much as geographic proximity. By aiming at more radical rather than incremental innovation, the customer's 
competence, complementary skill and interests as well as his proliferation capacity needs to be taken into consideration. Not all criteria are equally important for every project carried out with customers. Companies need to prioritize these criteria with regards to the specific innovation project into which a customer needs to be integrated.

The dependence on lead users' views can also be reduced by avoiding the integration of only one lead customer. Collaborating with a mix of lead users from different backgrounds and with different needs, working together in a workshop with internal experts, counterbalances a particular lead user's conscious or subconscious efforts to turn the search for ideas into a certain direction. In order to avoid the dependence on only one customer, Henkel established a continuous interface with consumers, in order to capture their desires, their habits and their worries at more than a single point of time. Different customer groups contribute to the innovation and bring in the consumers' perspective, which can be described as a sense and respond versus a make and sell. Henkel collects information about the consumer from different sources (consumer homework, which, for example, can be diaries, workshops, home visits, the "day in my life" empathic design tool with selected representative customers, internet platforms for broader inputs and fashion scouts to look for new trends from other industries and defining new lifestyles), aggregates it in a meaningful way and extracts the consumer insights. $B M W^{\prime}$ s marketing innovation lab follows a three-step approach in which ideas arriving through their website and customer emails are used to select trendsetting and technically capable lead users. In the next step, they were confronted with an idea like the functionalities of the man-machine interface in a future BMW series. Their ideas, created in brainstorming sessions in workshops, were discussed internally and the most valuable ones (or most in line with the company's innovation strategy) were developed and integrated into a prototype car. In a following step, representatives of the main customer groups are invited and shadowed when testing the man-machine interface prototypes in order to determine if the prototypes' design and function are appropriate and will gain appropriate acceptance. After optimizing and reducing the functionalities according to the learnings gained from the last step, market research is carried out to reduce the risk of failure even further as well as to determine how much customers are willing to pay for these new features.

\section{Dependence on Customers' Demands or Personality}

A customer, who asks to participate in the early innovation process and therefore invests his time and knowledge in the innovation to be created, sometimes demands exclusive rights to this innovation.
This can be a good development if the customer is the company's biggest or only customer for this product, because it entails having a ready buyer for the subsequent product. It can also be a bad development, however, if the company intends focusing on an economy of scale in order to benefit from the innovation and, in fact, needs to be free to sell the product to other - uninvolved - customers. Sulzer Hexis, a fuel cell company, builds power supplies for homes and competes with the big power suppliers. Because Sulzer Hexis delivers products for a decentralized electricity system, it needs a huge number of customers to achieve a profitable market position. The company therefore needs to be independent of a customer wanting exclusive rights. In order to avoid the risk of dependency, Sulzer Hexis integrates electricians (independent small service companies), who are in direct contact with the customers, in their innovation process instead of the huge power companies that dominate the market. Through the electricians' daily work at end consumers' homes, they gain a solid know-how of customers' problems and needs. In user meetings, which take place at the headquarter three times a year, the electricians and a team from Sulzer Hexis work on problems related to the production and installation of the fuel cells. Integrating customers or partners who can provide the necessary knowledge without being in a strong market position to demand exclusivity is one way of avoiding customer dependency.

One other way of reducing the risk of dependency on customers' demands is to refuse such a customer, even if it means not being able to integrate this customer, or - if his integration appears vitally important - to set up a parallel workshop with other customers if this is legally possible and economically sensible. BASF integrates different automotive OEMs into their search field process in order to minimize their market risk. To do so, BASF arranges workshops with selected automotive companies to test and outline their innovation fields. The search field "heat isolating glasses" proved to be an important chance for the company, which would have been neglected, if there had been only one automotive OEM.

Another problem concerning the customers could arise from their behavior/personality. A group of doubting Thomas's will never come up with a radical innovation, while a group of visionaries may overlook important details in the innovation process etc. This risk also applies to the personalities of the company employees involved in the innovation project. Not all R\&D teams are equally successful at working with customers. Besides projects need for customer integration, the engineers' personalities and attitudes when dealing with customers or their knowledge can - in the worst case - lead to this customer being lost for ever.

In this respect, risk management requires the help of the Human Resources (HR) employees. Ergonomics 
has established the importance of recognizing and making use of the different roles that people in cooperations play: the controller, agitator, "doer", doubter and the visionary (Hilb, 1990). These findings also apply to customers who are integrated into the innovation process. In setting up workshops with customers, innovation managers should take the various roles - both of the internal participants and of the customers - into consideration to guarantee a mix of different role-players. This is only possible with customers whom the company already knows from previous joint projects. Getzner Werkstoffe works closely together with the Deutsche Bahn, which had proved to be a reliable and solid customer during former projects. In frequent meetings with the customer, a trusting and innovative atmosphere was established. Helbling, a service company providing technical help in R\&D project, has established different, very customized, cooperation processes based on the knowledge gained with these customers over years of cooperation.

The risk arising from a customer's personal attitude or motivation can be lessened by taking the culture of the company from which he came (if this is relevant) prior to his integration into consideration. As a rule, integration of other companies' staff will only be successful if the company culture on both sides is compatible. The company considering integration should practice a culture of open communication in which all decisions are transparent. To achieve this aim, Henkel uses open communication and direct feedback regarding company strategy, customer expectations and failures as well as lessons learned. In order to reward innovative activities and facilitate an appropriate innovation atmosphere, Schindler Elevators implemented an Innovation Award with successful innovations being rewarded by an external jury and receiving a monetary reward from the top management. At the yearly Innovation Day at $K A B A$, innovators are publicly recognized for their innovation and their value to the company by the management, without an explicitly monetary compensation being provided.

A culture of open communication allows an organization to develop an absorptive capacity (Cohen and Levinthal, 1990) with strong learning effects necessary to integrate customer knowledge effectively. Getzner Werkstoffe tries to facilitate an innovative culture with frequent open communication with their customers. In 2005 Getzner will participate in more than 27 exhibitions worldwide in order to discuss new ideas with customers and competitors. Last year, this endeavor resulted in over 100 new development and product ideas. Getzner also organizes one conference for all of their distributors per year where each partner can present a new or interesting application in order to network and build new distribution and development collaborations.

By way of transferring knowledge, an efficient database and intranet management, as is practised by
$K A B A$, can help spread the new knowledge throughout the company. Through a central organization and a regional market development, it is possible for KABA to understand local conditions and to adapt products purposefully. The R\&D coordination is guided by KABA's 'Visio' organization. Interdisciplinary Visio teams in Europe and America are connected through the KabaNet and guided by a steering committee. The tasks of the Visio team are to identify and evaluate relevant market and technology trends. They are furthermore responsible for the development and exchange of knowledge and experience regarding technology, $R \& D$, and intellectual property between the strategic business segments and base product centers. A systematic portfolio evaluation of new products, or project ideas ensures focused R\&D activity in the most important areas. Merck, a leading pharmaceutical company, uses this method throughout the company. The innovation process starts with an evaluation of the internal technology and the application potential as well as with the screening of external ideas and technologies and own basic research. Afterwards more concrete and detailed competitor analysis, regional market analysis, and customer interviews are used, e.g. for the discovery of future color and vogue trends. Subsequently, a risk and a business analysis is undertaken and the projects will be arranged in an attractiveness-risk portfolio. An innovation rate evaluation of the projects is also undertaken. Ideally, such a culture of open communication also exists in the intended integrated customer's company.

The research, and especially the case studies with the aforementioned nine companies, have shown that an open exchange of ideas both within and outside the company is necessary. Furthermore, all companies that consider integrating customers should gather as much information about them as possible in order to assess their compatibility with the internal team this applies to all customers, irrespective of who they are.

\section{Limitation to Mere Incremental Innovations}

Customers helping with the innovation process rely on their experiences, which is why they were chosen in the first place (von Hippel, 1986). There is, however, the danger that this personal experience leads them to direct their thoughts and search in only one direction: how to improve the product with which they are familiar, rather than how to find a radically new one. Especially with normal customers, this so-called "functional fixedness" (von Hippel, 1986; Leonard, 2002) tends to prevent radical innovations and encourages only incremental ones.

To minimize the risk of being limited by customers to incremental innovations, the first step is to rely on lead users rather than on normal customers, because lead users have both the potential to develop and the 
motivation for radical innovations (Herstatt and von Hippel, 1992) and are known for their aboveaverage product involvement. It is furthermore considered effective by workshop participants to include "indirect" users/customers (e.g., soccer coaches for football or sportswear manufacturers) in mixed workshops, because their more detached and broader views help the other participants to avoid the pitfall of incremental ideas. Zumtobel, as mentioned before, likes to integrate designers and architects into the process of developing innovative electronic light devices and Sulzer Hexis, has had good experiences with integrating electrical fitters. Being experts themselves, they are able to pass this knowledge on without their clients' functional fixedness.

Another measure to prevent mere incremental innovation is the choice of the right method of integrating normal customers. IT-based tools - opinion portals, online communities, toolkits - provide access to a broad variety of users/customers. Their combined implicit knowledge, siphoned off by the IT-based tools and analyzed by experts, can compensate for the potential incremental inclinations that each individual customer using these tools may have (von Hippel and Katz, 2002). Henkel uses a similar toolkit for testing the scent of their washing powders. Customers needs differ from country to country and through an early integration of customers via toolkits, the company is able to provide the right scent for each country very quickly. E.g., in Germany the smell of chlorine after washing is frowned upon, whereas in Spain it is pleasing. Adidas has launched a web-portal for their new sports shoes where customers can assemble their personalized shoe by combining different components ranging from the color to the texture within the shoe and the design on the outside, to the materials used in the different parts. Adidas captures all this customer interaction in order to quickly deduce information regarding new trends.

Thirdly, the risk in question can be reduced by the intelligent timing of customer integration, which is more important than simply running the risk of a loss of know-how. Customers' early involvement, with its potential of having a strong impact on the innovation process, also offers opportunities to counterbalance one-sided views at later stages, or with the help of other internal or external sources. Infoterra (Geoinformation), for example, integrates customers as early as the drawing up of the business plan. Customers' ideas are therefore considered from the very beginning of the innovation process, yet there is enough time and opportunity to modify the direction of the search field process if necessary.

\section{Serving a Niche Market Only}

One of the many reasons for customer integration is that customers constitute a reliable buyer potential for products that were designed according to their needs (Prahalad and Ramaswamy, 2000). This advantage can quickly turn into a disadvantage when it becomes apparent that these customers, who represent only a small group, are the only ones interested in the newly created product. A mere niche market will hardly meet the company's expectations regarding sales and profit, as already illustrated in the Büchi example above. Henkel has learned this lesson and reacted as follows: They discovered that knowing both the product and the consumer reduces the risk of failure as well as giving the company a competitive advantage. They call it "consumer-inspired innovation", which means that they first pay attention to the consumer and analyze their sense and respond. The inspiration and stimulation from the consumer insights are used to develop successful innovations for the mass market.

In general, one can say that to counteract this risk, it is recommended that customer integration be implemented in two or three separate stages of the innovation process, using different customers in each: at the very beginning of the early innovation phase, in an advanced stage, and when testing prototypes. The $B M W$ example, mentioned above, points out what such a process could look like. Consequently, different prospective buyer groups can be considered, preventing the creation of a niche product. According to all the examined companies, dividing the early innovation phase into, for example, five or three stages is desirable, but not imperative and depends on a company's size. In the innovation process phases, small- and medium-sized companies do not need to systematize their processes and do not perform any better if the process is distinctly divided into stages, because the intuitive behavior of the few employees anyway follows a certain structure highly adapted to their company. For big companies the need to communicate best practices can only be followed by illustrating in order to distribute them to the various parts of the company. Especially when the different activities of the innovation process's early phase are taken over by different departments, or by different regional centers it is important to define when, how and which customer is best for what. The aforementioned stage division allows the company to integrate the selected customers with appropriate measures and with the aim of accumulating as many different opinions as possible at separate stages. This is even more important than various sophisticated tools. The early innovation phase is, however, ideal for setting up various stages because changes can be made easily (Kim and Wilemon, 2002). According to the research undertaken, the early innovation phase structure as illustrated by Figure 2 proved to be advantageous.

Figure 3 shows a possible structure for the early innovation phase. Five phases could be differentiated in the fuzzy front end: opportunity identification, idea generation, knowledge generation, concept definition and prototype development. They are structured in a 


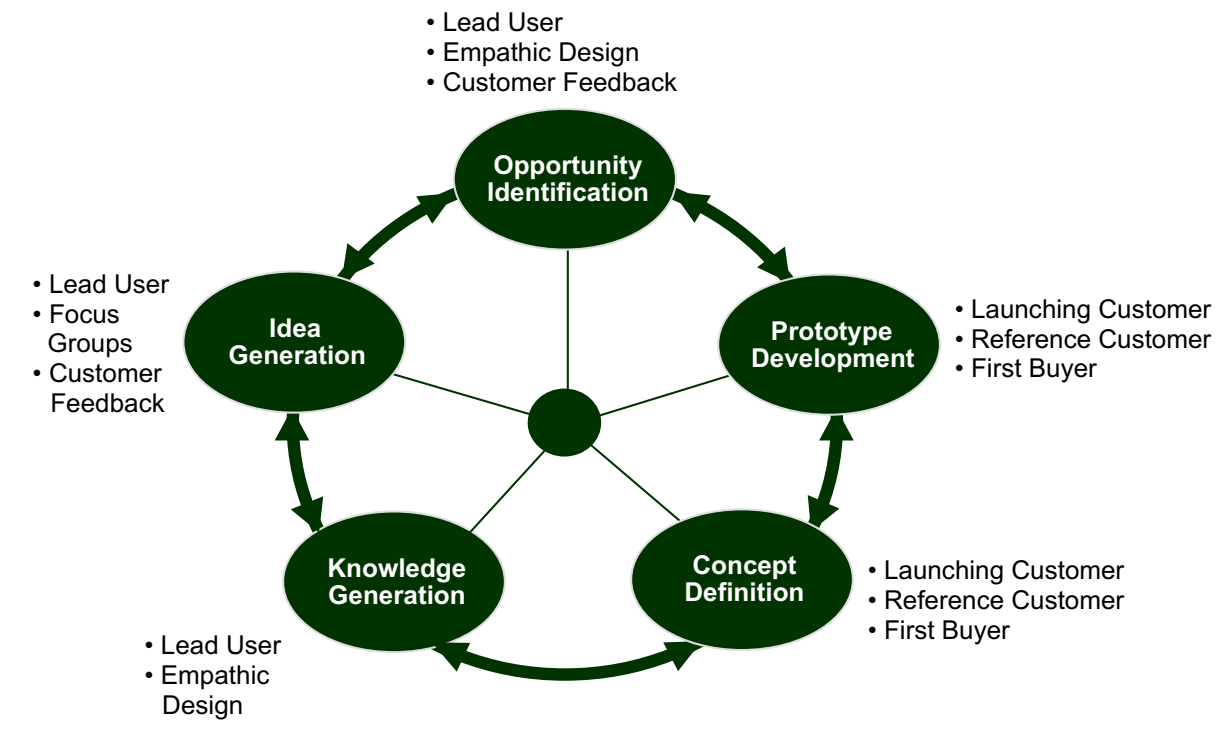

Figure 3 Different Phases in the Fuzzy Front End Required Different Methods and Customers to be Integrated

circle due to the fuzzy front end activities' iterative nature before starting with the new product development (Koen et al., 2001). The lead users play the most important role in the development of radical innovations and as trendsetters empower the company's ability to identify new search fields.

Secondly, by paying special attention to the search field process, which according to our structure belongs to opportunity identification, the risk of producing a niche market product following customer integration is minimized. This process is crucial for future innovation, whereas market research can only provide limited insights into existing markets and future trends (Lichtenthaler, 2003). A well-organized search field process will pay just enough attention to customers' ideas, needs, and wishes without overemphasizing them. Siemens, for example, used the Berlin city tram to develop and test the e-ticket. The city tram employees were involved in the early development stage and in testing both the prototype and the final product. However, due to circumspect innovation processing, the concept of the e-ticket is applicable in many other areas as well and is anything but a niche product.

Some success factors were identified for an effective innovation field process: the close contact of key accounts managers and/or the developer with the customers, limiting the number of customers selected for workshops while still ensuring their heterogeneity (Bonner and Walker, 2004), and finally, carefully selecting those customers who are going to participate. Depending on the innovation activities' aim and on the customers' specific needs, the right category of customers has to be chosen. This categorization should follow the framework set up by Brockhoff (2003). He identified five different types of customers: the launching customer, the lead user, the reference customer, the demanding customer, and the first buyer. These types of customers have different characteristics and capabilities that should be taken into account for purposeful integration in the search field process's different stages and which are imperative for the subsequent success of the cooperation. Sefar works together with lead users in the finding of a search field and idea generation. They emphasize radical innovations which are often beyond their current portfolio. If Sefar discovers that it does not have enough competencies to carry out a radical idea or concept, they search for launching customers to help them.

\section{Misunderstandings between Customers and Employees}

Quite often parts of customers' information disappear in the course of the integration process. This is sometimes due to misunderstandings that result from customers' inability to express their needs and wishes and to articulate the ideas they have for new developments (von Hippel, 1998). On the company's side, a loss or a distortion of customer input may occur when information gained by one department (e.g., marketing) has to be transferred to another one (e.g., R\&D). In addition, some R\&D teams are openly or secretly against cooperation with customers, resenting all external ideas (not-inventedhere syndrome).

The risk management process offers remedies for each of the different causes of the above-mentioned loss of information. Customers' misunderstanding can be reduced by integrating only those customers that have long-standing relationships with compa- 
nies, because they already understand these customers intimately. Existing contact with customers is an excellent basis for an in-depth collaboration and needs to be cultivated. There are several ways to get to know customers and maintain relationship. As mentioned before in some of the examples, trade fairs, sales and partner conferences are excellent places to establish and maintain relationships with customers and to get to know each other better before being caught up in an innovation project with all its inherent pressures. Panel workshops and workshops with market organization or value chain representatives offer another good chance to exchange thoughts and expectation, but also to test customers' opinions in order to select the appropriate customer to carry out an idea. Brain pools and cobranding as well as conjoint analysis are also mentioned as successful instruments to get to know the future development partner. Getzner, for example, frequently organizes scientific seminars with its lead customers and decision makers where they present new technologies and discuss ideas in order to realize new trends as early as possible and find appropriate co-developers. Besides this initiative, Getzner also frequently organizes scientific seminars for experts in this scientific field. In 2001, they organized and moderated the seminar on elasticizm in railways with great success. The invited all major rail companies from the German-speaking countries as well as engineering companies (like their competitors) and universities and invited them to present their major trends and new technologies. Getzner therefore learned more about their customers' and competitors' current and future activities. Their seminars are so successful in terms of the quality of the content as well as the number of companies wanting to participate that invitations to future seminars will be limited.

The not-invented-here syndrome can be overcome by incentive systems as an expression of, or support for the company's cultural change process, and offering rewards for cooperation with customers. The Schindler Elevators example as well as the previously mentioned $K A B A$ innovation day are good examples of those activities in practice, as is intensive contact between companies' engineers and customers. Although there is no contract-triggered pressure to integrate customers, IBM Rüschlikon strives towards external inputs without wishing to lose its leading role in driving innovation. The integration of customers and partners is supported by 350 workshops per year as well as by the 50-100 on-going research projects, product offers, integrated solutions and developing technologies. IBM's innovativeness is enriched by "innovation days" during which leading scientists, suppliers, customers and potential partners are invited to provide the company's research as a whole with external input and to stimulate discussions on mutual issues. Communication across company boundaries is seen as a way to obtain strategic alignment in research. Misunderstandings can be avoided with the help of the right method. The IT-based tools help customers to voice their ideas in ways that can easily be interpreted by those who install the specific software (Thomke and von Hippel, 2002). The anonymity of this method reduces customers' reluctance or reticence to articulate their needs, wishes, and suggestions. As was already shown by open source development, users mostly program lines of code in order to solve their own technical problems as well as those shared with others, and freely reveal their innovations without demanding payment for their software (von Hippel and von Krogh, 2003). However, according to the examined companies, this total IT-based customer integration has hitherto only been valuable for marketing and customer relationship purposes, whereas the success of user toolkits etc. for research activities cannot as yet be verified. However, as a configurator for different variants as used by Infoterra, this type of toolkit has been proved useful: customers are guided through a certain systematic which allows the use of different norms. In the latter case, however, it merely led to incremental innovations.

Misunderstandings may also be due to the fact that some projects are simply not suitable for integrating customers. Furthermore, not every research group in a company or every customer is willing and able to cooperatively interact. A way of eliminating integration risks is to thoroughly examine each innovation project in advance in respect of its general and particular suitability to involve customers.

\section{Conclusion and Recommendations}

The integration of customers into the innovation process has many advantages, but also holds definite risks: loss of know-how, dependence on customers, being limited to mere incremental innovations and niche markets, and misunderstandings (see the summary of risks and risk reducing activities in Figure 4).

These, however, are less important than the risk of not integrating customers at all, which will result in no market-driven products being produced and with the products' features not being valued or appreciated. Furthermore, the imperative of integrating customers is underlined by the danger of a bigger market risk through the lack of reference customers, an increase in R\&D costs through changes in products' features and the unnecessary limitation of innovative power as a result of not using an important source of innovation.

The balance in favor of customer integration must not lead to the inherent risks simply being accepted, but to managing them efficiently. Risk management should become an integral part of the overall innovation management. Depending on the specific risks, 


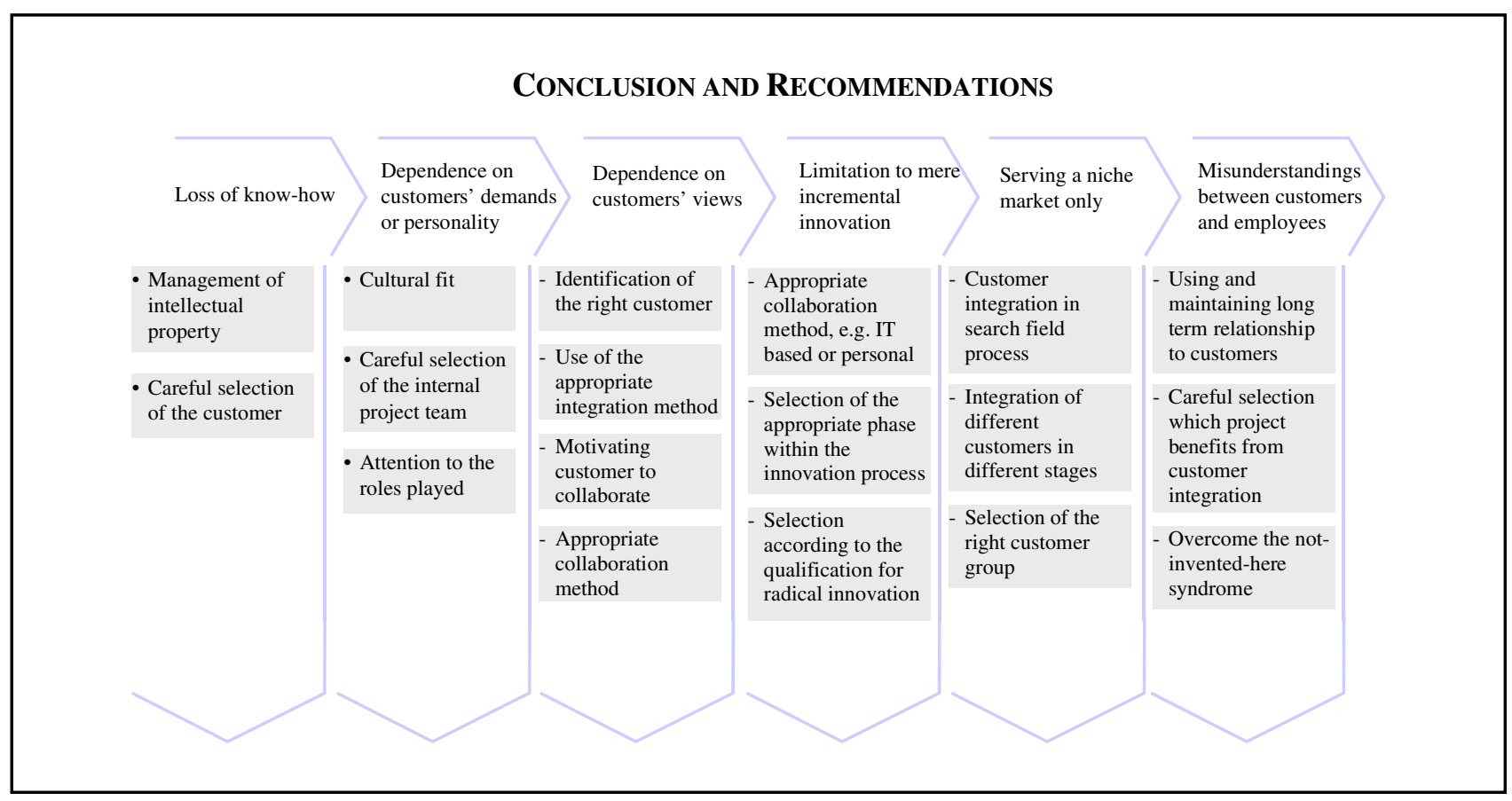

Figure 4 Summarizing Activities Minimizing the Risks of Customer Integration

specific measures for minimizing them are at managers' disposal:

* The selection of the right customers (preferably lead users) to be integrated,

* The choice of the right methods of integration,

* The choice of the right time and place for integrating customers into the innovation process,

* The provision of the right prevailing conditions (IP management, staff management, incentive systems among other things), and

* The choice of the right project in which the integration of customers creates a genuine added value.

Whereas future research on more refined and comprehensive methods is necessary, the measures for minimizing the risks of customer integration as described in this article should provide sufficient initial protection and encourage companies to tackle the required customer integration even more vigorously.

\section{References}

Becker, W. and Peters, J. (1998) R\&D-competition between vertical corporate networks: market structure and strategic R\&D-spillovers. Economics of Innovation and New Technology 6, 51.

Bonner, J.M. and Walker, O.C., Jr. (2004) Selecting influential business-to-business customers in new product development: relational embeddedness and knowledge heterogeneity considerations. Journal of Product Innovation Management 21, 155-169.

Brockhoff, K. (2003) Customers' perspectives of involvement in new product development. International Journal of Technology Management 26, 464481.
Bruce, M. and Biemans, W.G. (1995) Product Development: Meeting the Challenge of the Design Marketing Interface. Wiley, Chichester.

Chesbrough, H.W. (2003) Open Innovation: the New Imperative for Creating and Profiting from Technology. Harvard Business School Press, Cambridge.

Cohen, W.M. and Levinthal, D.A. (1990) Absorptive capacity: a new perspective on learning and innovation. Administrative Science Quarterly 35, 128.

Conway, S. (1995) Informal boundary-spanning communication in the innovation process: an empirical study. Technology Analysis and Strategic Management 7, 327ff.

Dahan, E. and Hauser, J.R. (2002) The virtual customer. Journal of Product Innovation Management 19, 332-353.

Gassmann, O., Enkel, E. (2004) In R\&D Management Conference (RADMA). Lisbon, Portugal.

Gassmann, O. and von Zedwitz, M. (1999) New concepts and trends in international R\&D organization. Research Policy 28, 231.

Hagedoorn, J. (2003) Sharing intellectual property rights an exploratory study of joint patenting amongst companies. Industrial Corporate Change 12, 1035-1050.

Herstatt, C. and von Hippel, E. (1992) From experience: developing new product concepts via the lead user method: a case study in a "low-tech" field. Journal of Product Innovation Management 9, 213-221.

Hilb, M. (1990) Ganzheitliches Personalmanagement: integriertes Konzept zur Personalselektion, -beurteilung, -belohnung und -entwicklung. HSG-Weiterbildungsstufe, St. Gallen.

Kim, J. and Wilemon, D. (2002) Strategic issues in managing innovation's fuzzy front-end. European Journal of Innovation Management 5, 27-39.

Koen, P., Ajamian, G., Burkart, R., Clamen, A., Davidson, J., D'Amore, R., Elkins, C., Herald, K., Incorvia, M. Johnson, A., Karol, R., Seibert, R., Slavejkov, A. and Wagner, K. (2001) Providing clarity and a common language to the 'Fuzzy Front End'. Research Technology Management 44, 46-55.

Leonard, D. (2002) The limitations of listening. Harvard Business Review 80, 93.

Leonard, D. and Rayport, J.F. (1997) Spark innovation through empathic design. Harvard Business Review 75, $102 \mathrm{ff}$. 
Lichtenthaler, E. (2003) Third generation management of technology intelligence processes. RED Management 33, 361-375.

Lilien, G.L., Morrison, P.D., Searls, K., Sonnack, M. and Von Hippel, E. (2002) Performance assessment of the lead user idea-generation process for new product development. Management Science 48, 1042.

Lukas, B.A. and Ferrell, O.C. (2000) The effect of market orientation on product innovation. Journal of the Academy of Marketing Science 28, 239.

Miotti, L. and Sachwald, F. (2003) Co-operative R\&D: why and with whom? An integrated framework of analysis. Research Policy 32, 1481-1499.

Prahalad, C.K. and Ramaswamy, V. (2000) Co-opting customer competence. Harvard Business Review 78, 79.

Thomke, S. and von Hippel, E. (2002) Customers as innovators: a new way to create value. Harvard Business Review 80, 8ff.
Urban, G.L. and von Hippel, E. (1988) Lead user analyses for the development of new industrial products. Management Science 34, 569ff.

von Hippel, E. (1986) Lead users: a source of novel product concepts. Management Science 32, 791-805.

von Hippel, E. (1998) Economics of product development by users: the impact of 'sticky' local information. Management Science 44, 629.

von Hippel, E. and Katz, R. (2002) Shifting innovation to users via toolkits. Management Science 48, 821ff.

von Hippel, E. and von Krogh, G. (2003) Open source software and the 'private-collective' innovation model: issues for organization science. Organization Science: A Journal of the Institute of Management Sciences 14, 209.

Wynstra, F. and Pierick, E.T. (2000) Managing supplier involvement in new product development: a portfolio approach. European Journal of Purchasing and Supply Management 6, 49-57.

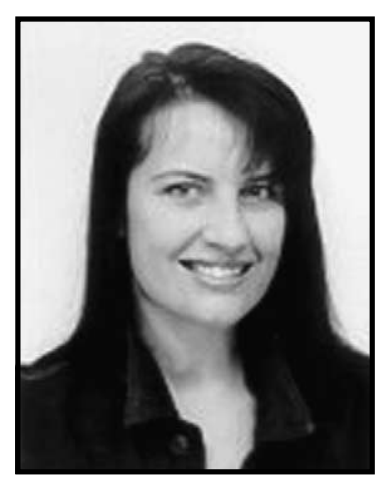

ELLEN ENKEL, University of St. Gallen, Institute of Technology Management, Dufourstrasse 40a, St. Gallen 9000, Switzerland. E-mail: ellen. enkel@unisg.ch

Ellen Enkel is Leader of the Competence Centre Open Innovation, at the University of St. Gallen. She researches into cooperative innovation processes and innovation networks within and across companies.

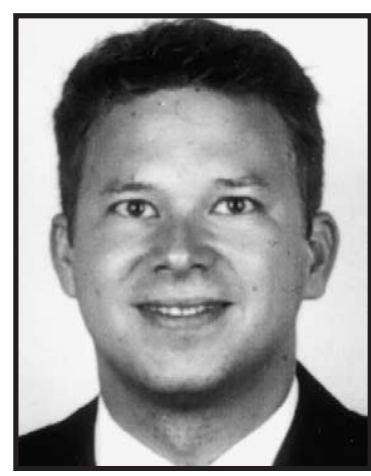

\section{CHRISTOPH}

KAUSCH, University of St. Gallen, Institute of Technology Management, Dufourstrasse 40a, St. Gallen 9000, Switzerland. E-mail:christoph.kausch@ unisg.ch

Christoph Kausch is Research Associate and doctoral candidate at the University of St. Gallen, researching into customer integration in the early innovation phases.

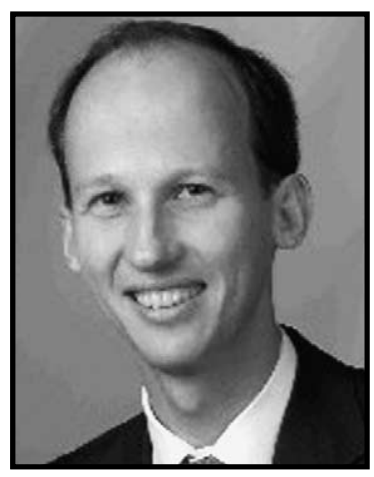

OLIVER GASSMANN, University of St. Gallen, Institute of Technology Management, Dufourstrasse 40a, St. Gallen 9000, Switzerland. E-mail: oliver.gassman@unisg.ch

Oliver Gassmann is Professor of Technology Management and Director of the Institute of Technology Management at the

University of St. Gallen. He has published seven books as author, co-author or editor, and over 100 articles in the area of technology and innovative management. 